\title{
KuRT MATULL
}

KASPAR HAUSER - STUMMFILM (1915)

Die früheste dokumentierte filmische Gestaltung des Stoffs liegt in dem Stummfilm Kaspar Hauser vor, zu dem Kurt Matull das Buch schrieb und Regie geführt hat. Der mit Jugendverbot belegte Film wurde auch unter dem Titel Die Tragödie des Kaspar Hauser gezeigt. Die Titelrolle spielte Josef Roemer-Saft vom Hoftheater Mannheim.

Mit diesem Stummfilm beginnt eine lange Reihe filmischer Bearbeitungen, zu denen auch Heinz Coubiers Der Spielverderber (1965) gehört. Internationalen Ruhm erlangte Werner Herzogs Verfilmung Jeder für sich und Gott gegen alle (1974).

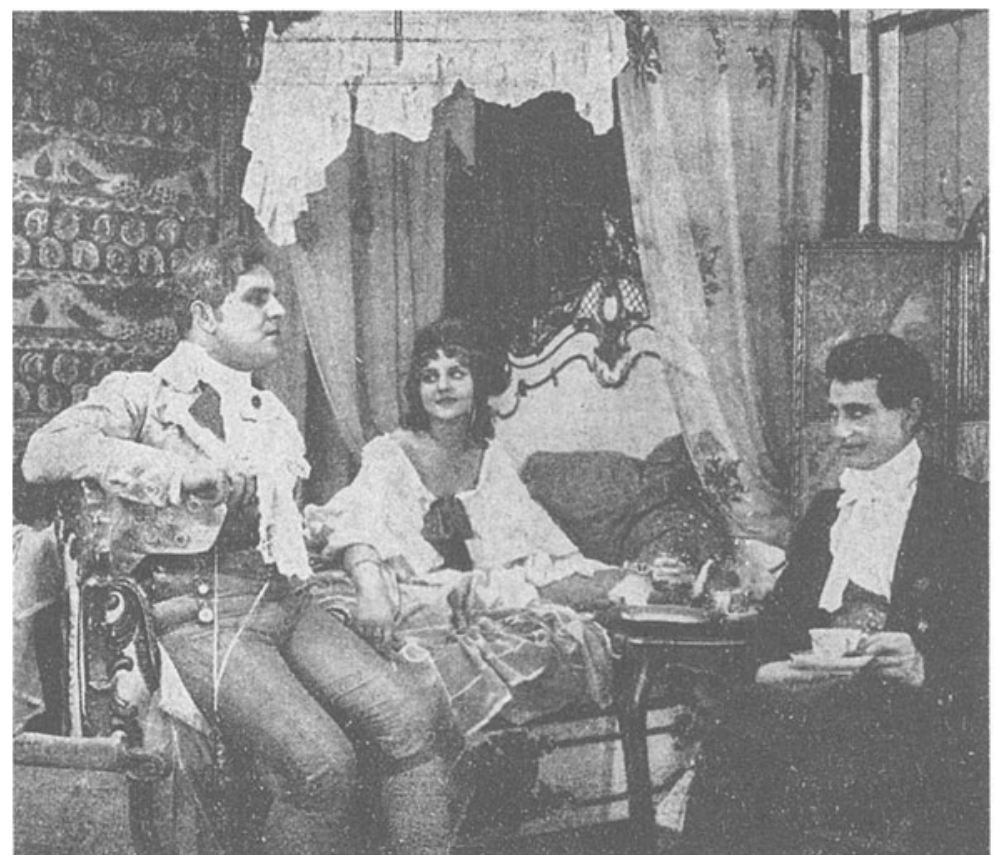

Lord Stanhope (links) im Gespräch mit Kaspar Hauser (rechts). 